\title{
Hannasofia Hardwick
}

\section{Vallan ja petoksen kuvat. Elokuvan ekfrasis Manuel Puigin romaanissa Hämähäkkinaisen suudelma}

Tarkastelen artikkelissani elokuvien sanallisia kuvauksia argentiinalaissyntyisen Manuel Puigin (1932-1990) romaanissa Hämähäkkinaisen suudelma (El beso de la mujer araña 1976; suom. Tarja Härkönen 2009, jatkossa viitteissä HS). Tutkin elokuvien sanallistamista suhteessa ekfrasiksen eli visuaalisen esityksen kirjallisen kuvauksen käsitteeseen ja siihen toistuvasti liitettyjen vallan, petoksen ja itsepetoksen attribuutteihin. Ekfrasiksen hyödyntäminen sopii erityisen hyvin Puigin teoksen analysoimiseen, sillä ekfrasis luo Hämähäkkinaisen suudelmaan eräänlaisen kaksoisvalotuksen: käsitteeseen yhdistettyjä ominaisuuksia voi tarkastella teoksen tematiikkaa vasten, ja yksittäisten elokuvien sanallistamiset toistavat romaanin tapahtumia. Samalla kuvaillut elokuvat painottavat henkilöhahmojen keskeisiä kipupisteitä, jotka puolestaan ilmentävät vallankäyttöä, manipulointia, petollisuutta ja itsepetosta. Tarkastelen artikkelissani myös sitä, miten ekfrasiksen määrittelyissä usein toistuva miehisen sanan ja naisellisen kuvauksen kohteen dikotomia suhteutuu romaanissa käsiteltävään homoseksuaalisuuden problematiikkaan ja elokuvien esittämiseen. Käsitys ekfrastisen prosessin sukupuolittuneisuudesta kyseenalaistuu teoksen kerronnan edetessä, ja elokuvien ekfrasikset ovat merkittävässä asemassa asetelman purkamisessa.

Ekfrasiksen käsite on peräisin antiikin Kreikasta, jossa sillä tarkoitettiin mitä tahansa sanallista kuvausta. ${ }^{1}$ Varhainen ekfrasis liittyy etenkin retoriikan alaan. ${ }^{2}$ Retoriikasta käsite siirtyi epiikkaan ja myöhemmin niin proosateoksiin kuin itsenäiseksi kirjalliseksi lajiksi (Scott 1991, 302; ekfrasiksesta varhaisissa romaaneissa ks. Reeves 2007; Bartsch 1989). Taideteokset ekfrasiksen kohteena yleistyivät myöhäisantiikissa. ${ }^{3}$ Käsite oli vuosisatoja unohduksissa, kunnes 1900-luvun puolivälissä akateeminen kiinnostus ekfrasista kohtaan heräsi. Samalla se rajoitettiin käsittämään ainoastaan taideteosten kirjalliset kuvaukset. (Webb 1999, 9-10.) Teoreetikot ovat antaneet nykymuotoiselle ekfrasikselle toisistaan poikkeavia määritelmiä (ks. esim. Clüver 1997, 26; Mitchell 1994, 164; Krieger 1992, 6; Steiner 1982, 41). Itse hyödynnän James Heffernanin $(1993,3)$ määritelmää ekfrasiksesta visuaalisen esityksen sanallisena esityksenä, mikä kattaa myös elokuvan kaltaisen audiovisuaalisen esitysmuodon. ${ }^{4}$

Ekfrasiksen käsitteen soveltaminen elokuvien kaunokirjallisiin kuvauksiin on hedelmällistä, sillä staattisten kuvien sanallistamiseen verrattuna elokuva tarjoaa huomattavasti kompleksisemman, ajassa ja tilassa muuttuvan kuvauksen kohteen, jolla on oma 
narratiivinsa. Lisäksi elokuva on niin esitysmuotona kuin kokemuksena todellisuuden ja fantasian välillä tasapainotteleva ilmiö, ja vertautuu siten ekfrasiksen kuvallisia illuusioita aiheuttavaan toimintaan. Elokuvan kokemisprosessi tekee katsojan tietoiseksi todellisuuden ja kuvitellun rajoista sekä niiden välisestä rajankäynnistä (ks. Kuhn 2002, 184-186; McConnell 1975, 2). Samat ilmiöt koskevat kaunokirjallisuuden ja siten ekfrastisen kerronnan vastaanottoa (ks. Bram 2006, 374).

\section{Romaanista ja elokuvien ekfrasiksista}

Hämähäkkinaisen suudelma kertoo kahdesta hyvin erilaisesta miesvangista ja heidän välilleen kehittyvästä eroottisesta suhteesta. Homoseksuaali Molina jakaa sellin vasemmistoaktivisti Valentínin kanssa. Iltaisin Molina selostaa ajankuluksi Valentínille näkemiään elokuvia. Erimielisyyksistä huolimatta Molina huolehtii Valentínista tämän sairastuttua ja jakaa ruokapakettinsa tämän kanssa. Molinan toimet asettuvat kuitenkin uuteen valoon romaanin puolivälissä lukijan saadessa tietää, että Molina on suostunut hankkimaan Valentínilta tietoja vasemmistoradikaaleista. Palkkioksi urkinnasta vankilan johto on luvannut vapauttaa Molinan.

Molina ei kuitenkaan yritä saada Valentínilta tietoja tämän poliittisesta toiminnasta; päinvastoin hän kieltää tätä kertomasta mitään vallankumousryhmästä ja samalla hyötyy vankilanjohtajan kanssa tehdystä sopimuksestaan kuittaamalla runsaita ruokapaketteja. Helliessään mistään tietämätöntä Valentínia Molinan onnistuu lopulta vietellä tämä, ja he alkavat viettää öitä yhdessä. Yllättäen Molina päätetään vapauttaa. Hän lupaa välittää Valentínin vasemmistoradikaaleille tarkoitetun viestin. Tehtävä koituu kuitenkin Molinan kohtaloksi, sillä hänet ammutaan. Syylliset ovat mitä oletettavimmin Molinan rehellisyyttä epäileviä vasemmistolaisia.

Valtaosa Hämähäkkinaisen suudelmassa esiintyvistä elokuvien ekfrasiksista on Molinan Valentínille esittämiä. Lisäksi muutama elokuvakertomus on sisäisen monologin muodossa: Molina selostaa yhden elokuvan mielessään itselleen, ja Valentín puolestaan luo oman versionsa eräästä Molinan aiemmin kuvailemasta elokuvasta yöllisen kuumehoureen sivutuotteena. Teoksen kerronta on pääosin Molinan ja Valentínin välistä dialogia. Sellitoverusten välisten keskustelujen lisäksi dialogia esiintyy muutamassa Molinan ja vankilanjohdon välisessä jaksossa. Lisäksi romaanin lopussa on pitkä viranomaisten laatima raportti Molinan toimista tämän vapauduttua vankilasta. Romaanissa on myös runsaasti alaviitteitä, joissa esitellään akateemisen asiallisesti erilaisia teorioita homoseksuaalisuuden syistä. ${ }^{5}$ Vaikka Hämähäkkinaisen suudelmassa on siis kolmannen persoonan kerrontaa, lukijalle ei anneta tietoa fiktiivisestä maailmasta. Lukija on rajoittunut henkilöhahmojen suoriin puhe-esityksiin sekä jaksoihin, joissa kuvataan heidän ajatuksiaan. ${ }^{6}$ 
Hämähäkkinaisen suudelmassa kielellistetään yhteensä kuusi elokuvaa, joista puolet on todellisia ja puolet fiktiivisiä. Ensimmäinen kerrottu elokuva perustuu Jacques Tourneurin vuonna 1942 ohjaamaan kauhuelokuvaan Cat People (suom. Kissaihmiset). Järjestyksessä kolmas romaanissa selostettava elokuva pohjaa John Cromwellin melodraamaan The Enchanted Cottage (suom. Rakkauden silmin) vuodelta 1945. Viidentenä kuvaillaan elokuva I Walked with a Zombie (1943, suom. Yö voodoo-saarella), joka on myös Tourneurin ohjaama. Kuvitteellisista elokuvista vain ensimmäiselle (järjestyksessä toisena teoksessa selostettavalle) elokuvalle annetaan nimi, "Kohtalo", joka mukailee natsi-Saksan propagandistisia elokuvia. Kahta muuta romaanissa kuvailtavaa fiktiivistä elokuvaa ei nimetä, mutta niitä on Hämähäkkinaisen suudelmaan liittyvässä tutkimuksessa kutsuttu "Seikkailuelokuvaksi" ja "Meksikolaiselokuvaksi". Edellinen, seurapiirielämää ja sissitaisteluja yhdistävä jännitysdraama on järjestyksessä neljäs romaanissa selostettava elokuva. Jälkimmäinen on niin ikään romanttinen melodraama, ja se esitetään romaanissa viimeisenä.

Hämähäkkinaisen suudelmassa ääneen kuvaillut ja mielessä ajatellut elokuvat rytmittävät Valentínin ja Molinan suhteen vaiheita ja luovat puitteet heidän keskusteluilleen. Yhtä tärkeitä ovat kuitenkin kielletyt tai vaietut puheenaiheet: Valentínin monimutkaiset perhesuhteet, Molinan poliittinen valveutuneisuus ja hänen huono itsetuntonsa. Aiheet julistetaan aluksi tabuiksi enemmän tai vähemmän eksplisiittisesti - ja samalla tietoisesti - mutta niiden rooli Molinan ja Valentínin suhteen kehittymisessä on merkittävä, sillä aiheiden myöhempi käsittely lisää henkilöhahmojen välistä ymmärrystä. Romaanin alkuosassa nopeasti rakentuva vastakkainasettelu Molinan ja Valentínin välillä katoaakin asteittain toisessa osassa, ja heidän kanssakäymisensä saa uuden, homoeroottisen ulottuvuuden. Suhteen syvenemiseen vaikuttaa osaltaan juuri elokuvien kertominen, mikä vahvistaa elokuvien ekfrasisten ja ongelmallisten seksuaaliidentiteettien välistä kytköstä teoksessa. ${ }^{7}$

Romaanissa esitetyt elokuvat siis heijastelevat yhteisessä vankisellissä viruvien Molinan ja Valentínin elämäntilannetta, mielenmaisemaa sekä heissä tapahtuvia muutoksia kerronnan edetessä. Elokuvat toimivat eräänlaisina stimuloivina katalyytteinä, jotka saavat heidät käsittelemään salattuja piirteitään, lausumattomia ajatuksiaan ja seksuaalisuuteensa liittyviä kysymyksiä. Samalla elokuvat ilmentävät romaanin kuvaamaa yhteiskuntaa eli 1970-luvun diktatuurin hallitsemaa, konservatiivisen ja samalla voimakkaan heteronormatiivisen patriarkaatin puristuksessa elävää Argentiinaa sekä sen vangitsemia uhreja, homoseksuaalia Molinaa ja marxistiradikaalia Valentínia. ${ }^{8}$ Romaanissa esitetyt henkilöhahmojen yksityiset ongelmat sekä yhteiskunta- ja seksuaalipoliittiset kysymykset heijastuvat selvästi elokuviin ja niiden selostamiseen. 


\section{Vallankäyttö ja manipulaatio}

Nykytutkimuksessa ekfrasis on yhdistetty toistuvasti valtaan, petokseen ja itsepetokseen. Tendenssi näkyy niin käsitteen teoretisoinnissa kuin yksittäisissä teosanalyyseissä (ks. esim. Mitchell 194, 157; Heffernan 1993, 7; Mandelker 1991, 1; Scott 1991, 302; Gysin 1989, 160). Hämähäkkinaisen suudelma toisintaa ekfrasiksen käsitteeseen liitettyjä vallan ja (itse)petoksen piirteitä eri tavoin. Vallankäyttö ja mahdollisuus petollisuuteen ovat nähtävissä jo romaanin tarinamaailmassa, merkittävimpinä Molinan ja Valentínin suhteen implikoima manipulaatio ja kautta romaanin muuntuvat valta-asetelmat. Molinan ja vankilanjohdon välisessä kommunikaatiossa on myös nähtävissä vallankäyttöä, sillä vangin ja vangitsijan suhdetta leimaavat sopimukset, tiedon panttaaminen ja suoranainen valehtelu. Esimerkiksi Molinan ja vankilanjohdon tekemä sopimus johtaa tilanteeseen, jossa lopulta molemmat osapuolet pettävät: Molina pidättäytyy kertomasta Valentínin toimista kapinallisliikkeessä, ja vankilanjohtaja päättää käyttää Molinaa syöttinä kapinallisten kiinnisaamisessa.

Valtapelin ja manipuloinnin lisäksi vangit sortuvat toistuvasti itsepetokseen ja eskapismiin. Esimerkkinä itsepetoksesta ovat jo edellä mainitut kielletyt puheenaiheet. Molinalla itsepetos ja eskapismi yhdistyvät myös elokuviin ja niiden selostamiseen, sillä hän haluaa paeta iltaisin melodraamojen maailmaan. Molina myöntää tarvitsevansa mielikuvituksen tuomaa lohtua vankeudessa, sillä muuten hän pelkää sekoavansa (HS 88). Selostettujen elokuvien henkilöhahmot tarjoavat myös vastineen itsepetokseen taipuvaiselle Molinalle. Santiago Colás $(1994,82)$ on todennut, että Molinan pakomatka elokuviin on yhtä ristiriitaista ja illusorista kuin ensimmäisen selostetun elokuvan Cat Peoplen naispäähenkilön Irenan pako sisäiseen maailmaansa. ${ }^{9}$ Irenan käytös johtuu hänen päälleen langenneesta kirouksesta, jonka mukaan hän muuttuu pantteriksi tuntiessaan eroottista mielihyvää. Niin Molina kuin Irena turvautuvat siis ahdistuksen hetkellä mielekkääksi arvioimaansa vaihtoehtoon, mikä ei kuitenkaan ratkaise heidän ongelmiaan.

Elokuvien selostamiseen liittyvä eskapistinen halu paeta ankeaa todellisuutta vankisellissä näyttäytyy myös toisella tavalla. Ekfrasiksen ja romaanin esittämän todellisuuden välinen ristiriita näkyy nimittäin elokuvan synnyttämän illuusion tuottamana mielihyvänä ja tuntemuksen romuttumisena elokuvan ulkopuolisten tekijöiden takia. Tämä ilmenee esimerkiksi seuraavasta Molinan puuskahduksesta: "olen tosi vihainen sinulle, kun aloit jauhaa tuosta, sillä minulla oli upeaa siihen asti, unohdin tämän saastaisen sellin ja kaiken kun kerroin sitä leffaa” (HS 22). Näin voi käydä myös lukijalle, sillä elokuvakertomukset vievät helposti mennessään. Eskapismia ei tule kuitenkaan tarkastella pelkästään todellisuuspakoisena käytäntönä. Juuri elokuvien selostaminen tarjoaa vangituille Molinalle ja Valentínille mahdollisuuden käsitellä heidän ongelmiaan ja kuvitella vaihtoehtoja vallitseville olosuhteille (ks. Dyer 2002, 25). 
Molina on joutunut homoseksuaalisuutensa takia yhteiskunnan vainoamaksi, ja elokuvat representoivat hänen kokemaansa repressiota. Esittämällä traagisia tarinoita naisten tukalasta asemasta maskuliinisuuden kyllästämässä maailmassa Molina korostaa samalla problemaattista seksuaali-identiteettiään. ${ }^{10}$ Yhtäältä elokuvat toimivat siis itseilmaisun kanavana; toisaalta ne mahdollistavat ongelmien suoran verbalisoinnin sivuuttamisen. Elokuvakertomukset eivät kuitenkaan ainoastaan välitä henkilökohtaisia viestejä vaan myös pakottavat nahistelevat sellitoverukset kohtaamaan heitä häiritsevät piirteet toisissaan - ja itsessään. Molinan ja Valentínin väliset konfliktit johtuvat nimittäin pääosin siitä, että he näkevät toisissaan ominaisuuksia, joita he pyrkivät torjumaan itsestään, mutta joiden eteen he väistämättä joutuvat esitettyjen elokuvien takia (ks. Colás 1994, 86-87). ${ }^{11}$ Samalla ekfrasiksen kyky heijastaa kuvatun esityksen peilikuva omaan itseen tuo uuden yhtymäkohdan ekfrasiksen ja Hämähäkkinaisen suudelman itsepetoksen teemaan (ks. Mandelker 1991, 11).

Ekfrastista projektiota käsitellyt Tamar Yacobi (2000) on kiinnittänyt huomiota ekfrastisen kahdentumisen mahdollisuuteen eli siihen, että jostakin laukaisevasta tekijästä johtuen ekfrastinen puhuja saattaa siirtyä visuaalisen (uudelleen)kuvailusta puhumaan itsestään (mt., 730). Esittämänsä visuaalisen tulkinnan kautta puhuja pettää itseään tiedostamattaan, ja itsepetos heijastuu juuri ekfrasikseen (mt., 735). Yacobin mukaan kuvattu taideteos on siten peili katsojan sieluun, jota ilmennetään ekfrastisen kahdentamisen kautta (mt., 736). Yacobin näkemykset pätevät oivallisesti Molinan ja Valentínin asemaan ekfrasisten esittäjinä: tärkeintä eivät ole selostetut elokuvat, vaan niiden kautta tietoisesti tai epätietoisesti välitetty viesti. Lisäksi heihin voi soveltaa Yacobin (1995, 643-644) esittämää ajatusta visuaalisen esityksen ja puhujan psyyken välisestä suhteesta: elokuvat toimivat henkilöhahmojen alitajuisten ja salattujen ajatusten vertauskuvana sekä niiden käsittelyalueena.

Molinan tavoin Valentínilla on taipumus itsensä pettämiseen. Hän esimerkiksi uskoo vakaasti, ettei sellin ulkopuolella vallitseva sortava yhteiskuntajärjestelmä pysty vaikuttamaan heihin:

Tavallaan me olemme täysin vapaita toimimaan niin kuin haluamme suhteessa toisiimme, ymmärrätkö? [--] tämän sellin ulkopuolella meillä voi olla sortajia, mutta sisäpuolella ei ole. Täällä meitä ei sorra kukaan. (HS 226.)

Valentín on tietenkin väärässä, sillä he toistavat suljetussa tilassa perinteisiä valtaasetelmia ja manipuloivat toisiaan sekä tietoisesti että tiedostamattaan. Poliittista aktivismiaan kiihkeästi puolustava Valentín ajautuu teoksen lopulla pohtimaan yhteiskunnallisen radikalisminsa arvoa elämässään: "minua raivostuttaa olla marttyyri, en ole hyvä marttyyri, ja tällä hetkellä minusta tuntuu että kaikki on ollut erehdystä" (HS 199). 
Vallan ja petoksen tematiikka ilmenee myös Molinan Valentínille selostamissa elokuvissa. ${ }^{12}$ Etenkin kuvitteelliset "Meksikolaiselokuva" ja propagandistinen "Kohtalo" edustavat suureellista melodraamaa: vastoinkäymisistä kärsivät päähenkilöt joutuvat petosten ja itsepetoksen uhreiksi ja saavat traagisen lopun. Esitetyissä elokuvissa tapahtuvat ilmiöt puolestaan toistuvat romaanin fiktiivisessä todellisuudessa ja kytkeytyvät siten romaanin tapahtumiin ja etenemiseen. Vavahduttavimpana esimerkkinä on romaanin lopussa poliisiraportin muodossa esitettävä Molinan väkivaltainen kuolema.

\section{Sanan vääristävä ja houkutteleva voima}

Hämähäkkinaisen suudelmassa ekfrastisen kerronnan ja ekfrasiksen käsitteeseen usein liitetyn vallankäytön suhde on erityisen vahva. Ensinnäkin Molinan voi tulkita tiedonhaltijaksi ja siten valta-aseman pitäjäksi hänen puhuessaan Valentínille elokuvista, joita tämä ei tunne (ks. Yacobi 2000, 743). ${ }^{13}$ Valentín ei puolestaan saavuta vastaavaa auktoriteettiasemaa, sillä hän versioi elokuvia ainoastaan omassa mielessään. Toiseksi Molina vaikuttaa olevan tietoinen asemastaan ja käyttää sitä hyväkseen muokkaamalla faktuaalisia elokuvia ja ylläpitämällä jännitystä keskeytyksin: "vien tikkarisi jemmaan juuri kun se maistuu makeimmalta, niin nautit leffasta enemmän” (HS 32). ${ }^{14}$

Sanan oletetun voiman voi havaita myös romaanin kerronnallisessa muodossa. Huolimatta siitä että teoksessa käsitellään jatkuvasti visuaalista materiaalia, kerronta on riisuttu fiktiivisen todellisuuden esittämisestä. Ratkaisu on epäilemättä harkittu: yhtäältä se suhteutuu kiinnostavasti esitettyjen elokuvien visuaalisen kuvailun runsauteen ja mielikuvituksen asemaan kerronnassa, ja toisaalta se korostaa sanojen valtaa ja voimaa teoksessa.

Molinan elokuvaselostuksissa korostuu omakohtaisuus. Hän tuo selvästi esille katsomiskokemuksensa, kuten kuvatessaan "Kohtalon" musiikkikohtausta:

yhtäkkiä kankaalla näkyy upea pariisilaisteatteri, se on kertakaikkisen fantastinen, kaikki on verhoiltu tummalla sametilla, parvien kaiteet on kromattu ja myös portaat ja porraskaiteet on kromattu kaikki. Se on music-hall, ja paraikaa on menossa musiikkinumero jossa on vain kuorotyttöjä, aivan jumalainen vartalo jokaisella, tulen muistamaan sen esityksen lopun ikäni. (HS 57.)

Yksikään elokuvaselostus romaanissa ei välty voimakkaalta subjektiivisuudelta, mutta toisinaan Molina verhoaa reaktionsa ovelasti koko yleisöä koskevaksi tuntemukseksi: "Sitten kamera kääntyy uudelleen kohti hopeista puutarhaa, ja katsoja istuu elokuvateatterissa, vaikka hänestä tuntuu kuin hän olisi lintu joka nousee lentoon" (HS 64).

Molinan yksityiskohtaiset kuvailut toimivat edustavina esimerkkeinä W. J. T. Mitchellin (1994, 154) esittämästä toteamuksesta, jonka mukaan ekfrasis kykenee esittämään erittäin laajaa aistikokemusten skaalaa. Kokemuksellisuuden painottuminen ekfrasiksissa ei kuitenkaan poista sitä tosiasiaa, että Molina muokkaa selostuksis- 
saan faktuaalisia elokuvia tunnistamattomiksi. Kokemuksen korostuminen Molinan ekfrasiksissa ei selitä hänen taipumustaan muuttaa elokuvien sisältöä. Todennäköisempää on, että kuvailemalla elokuvia tietyllä tavalla Molina pyrkii vaikuttamaan kuulijaansa, Valentíniin.

Ekfrasis liittyy etenkin näkökyvyllä saatuun informaatioon. Siten ekfrasis horjuttaa modernia käsitystä siitä, ettei tietämisen ja näkemisen välillä ole epistemologista vastaavuutta (ks. Esrock 1994, 183). Ellen Esrock onkin todennut, että tiedon ja näköaistin välisen vastaavuuden emotionaalinen voima säilyy useilla ihmisillä tieteellisistä näkemyksistä huolimatta (mt.). Hämähäkkinaisen suudelmassa näkökyvyn voima on huomattava huolimatta siitä - tai kenties juuri sen takia - ettei romaanissa ole lainkaan fiktiivistä todellisuutta kuvaavia jaksoja. Ekfrasiksen epistemologisella ulottuvuudella on puolestaan suora yhteys valtaan ja sosiaaliseen toimintaan. Representaatiota tutkinut Mitchell $(1994,180)$ katsoo, että ekfrastinen toiminta paljastaa usein esittämiseen kytkeytyvän sosiaalisen rakenteen, jossa valta, tieto ja halu ovat suhteessa toisiinsa ja toimivat aktiivisesti ekfrasiksessa. Hämähäkkinaisen suudelmaan pätee erityisen hyvin Mitchellin näkemys, jonka mukaan representaatio on aktiivinen prosessi, jossa tehdään jollekin jotakin, jonkin kanssa, jonkin avulla ja jotakuta varten (mt.).

Molina on Mitchellin kuvailema aktiivinen toimija. Elokuvia selostamalla hän vihjailee Valentínille seksuaalisesta kanssakäymisestä ja estoista vapautumisesta. Lisäksi hän pyrkii viihdyttämään Valentínia ja tavoittelee tämän suosiota saavuttaakseen haluamansa. Elokuvatarinoiden muotoon naamioitu pyrkimys vaikuttaa Valentíniin näkyy heti ensimmäisen selostetun elokuvan eli Cat Peoplen kohdalla. Molinan on kaunisteltava ja muokattava alkuperäisen elokuvan naispäähenkilöä Irenaa, jotta Valentín voisi tuntea myötätuntoa naista ja samalla myös homoseksuaalia Molinaa kohtaan, sillä Molinahan jakaa tietyssä mielessä vainotun ja ei-ymmärretyn Irenan kohtalon. Hämähäkkinaisen suudelman ekfrasikset osoittavat Molinan laajan elokuvatietämyksen ja hänen kykynsä muokata niiden tarinoita pyrkimystensä mukaisiksi. Lisäksi Molina mainitsee vain harvoin selostamansa elokuvan tai siinä esiintyviä näyttelijöitä nimeltä. ${ }^{15}$ Elokuvista tulee siten entistä voimakkaammin Molinan omia taideteoksia.

Itseä korostavasta tyylistä voidaan päätellä, että elokuvien kuvailemisen taustalla olevat henkilökohtaiset tavoitteet ovat varsin ilmeiset. Samalla ekfrasiksen rakenne sosiaalisena vallan ja halun näyttämönä näyttäytyy paljaana. Romaanissa ilmenevät manipulaation ja petollisuuden muodot saavuttavat myös lukijan, joka saa tietää Molinan sopimuksesta vankilanjohdon kanssa (Bacarisse 1988, 90). Yllättävää paljastusta seuraavat tapahtumat pitävät lukijan kiinnostusta yllä, minkä takia Pamela Bacarisse rinnastaakin lukijan Valentíniin, joka on hänen mukaansa hämähäkkinaisen eli Molinan verkossa (mt.). 


\section{Binaarisen sukupuolijaottelun problematiikka}

Ekfrasista, Hämähäkkinaisen suudelmaa sekä vallan ja (itse)petoksen teemoja yhdistävät myös klassisiin sukupuolikäsityksiin ja heterorormatiivisuuteen liittyvät kysymykset. Vanhanaikaisen sukupuolierottelun voi kiinnostavasti nähdä useissa ekfrasiksen nykymääritelmissä (ks. erit. Mitchell 1994, 168; Heffernan 1993, 1; Scott 1991, 305). Esimerkiksi Heffernanin (mt.) mukaan ekfrasiksen ilmentämä taistelu kuvan ja sanan välillä on usein hyvin sukupuolittunutta. Tämä johtuu hänen mukaansa siitä, että ekfrasiksessa miehinen ääni pyrkii hallitsemaan kiehtovaa ja samanaikaisesti uhkaavaa feminiinistä kuvaa. Heffernanin mielestä miehinen kerronta pyrkii siis torjumaan kauniin objektin tuottaman huumaavan vaikutuksen. (Mt.) Kuitenkin kuvat, joille ekfrasis on antanut äänen, puhuvat ja katsovat takaisin mieskatsojaan ja haastavat siten miehisen katseen kontrolloivan auktoriteetin ja miehisen sanan voiman (mt., 7).

Ekfrasiksen teoretisoinnissa hyödynnettyä sukupuolten välistä oppositioasetelmaa vasten on kiinnostavaa tutkia Hämähäkkinaisen suudelmaa, sillä siinä voi havaita samanlaisia binaarisia rakenteita. Etenkin vanhojen elokuvien ilmentämien normatiivisten sukupuoli- ja seksuaali-identiteettien esittäminen sekä Molinan taipumus ihailla klassisen Hollywood-elokuvan naiskuvaa toistavat perinteisiä käsityksiä aktiivisesta miehestä ja passiivisesta naisesta. ${ }^{16}$ Vaikka vanhanaikainen käsitys tiukoista mies- ja naissukupuoleen kohdistuvista odotuksista vaikuttaa ensi näkemältä soveltuvan romaanin henkilöhahmojen representoimiin sukupuoli- ja seksuaali-identiteetteihin, näkemys kadottaa tarkemmassa analyysissä mielekkyytensä. Samalla ekfrasikseen yhdistetty tiukka kahtiajako kyseenalaistuu, kun Molinan ja Valentínin elokuvaselostuksia tarkastellaan suhteessa teoksessa esiintyviin sukupuoleen ja seksuaalisuuteen liittyviin ilmiöihin ja ongelmiin.

Molinan romanttisuus ja herkkyys tekevät hänestä kuvailemiensa populaarielokuvien stereotyyppisen, alistuvan ja miehestä riippuvaisen naisen: "Se jokin tulee siitä että kun mies pitää naista sylissä... naista pelottaa vähän” (HS 271). Molinalla on taipumus tulkita etenkin naispuolisten henkilöhahmojen tunne- ja ajatusmaailmaa, ja hän myöntää Valentínille puolueellisuutensa ja voimakkaan samastumisensa naispääosanesittäjiin: "Minä pidän aina sankarittaren puolta" (HS 31). Jo romaanin alkupuolella Molina julistaa Valentínille haluavansa "olla nainen" (HS 25). Myöhemmin avoimesti homoseksuaali Molina määrittelee itsensä ja kaltaisensa "tiiteiksi", painottaakseen eroa muihin "homoihin": "Me olemme normaaleja naisia ja makaamme miesten kanssa" (HS 227).

Valentín puolestaan huokuu miehekkyyttä ja kyynisyyttä. Vallankumouksesta haaveileva Valentín suhtautuu epäuskoisesti yksiavioisuuteen ja näkee tunteiden ja aistillisuuden olevan mitättömiä yhteiskunnallisten muutosten toteuttamisen rinnalla. Valentín ikävöi kuitenkin valtavasti tyttöystäväänsä ja osoittaa herkkyyttä ja tunteikkuutta samastuessaan elokuvan henkilöhahmoihin ja harmitellessaan Molinan ensim- 
mäisen elokuvakertomuksen päättymistä: "Olen pahoillani siksi että kiinnyin niihin henkilöihin. Ja nyt kun tarina on ohi, tuntuu kuin he olisivat kuolleet." (HS 48.) Molinalle luonnolliselta tuntuva samastuminen aiheuttaa Valentínissa ihmetystä ja ilmeistä harmia, sillä se osoittaa vasemmistoradikaalille sopimatonta herkkyyttä: "Merkillistä miten ihmisen pitää aina kiintyä johonkin" (HS 49). Selostettujen elokuvien henkilöhahmoissa aiheuttamat reaktiot paljastavat siten vaivihkaa heidän olennaisia ja usein heiltä itseltään(kin) salattuja ominaisuuksia. Samalla ekfrasiksen oletettu sukupuolittunut rakennelma alkaa horjua.

Molina ja Valentín ovat ekfrastisina puhujina ja seksuaali-identiteettinsä ilmaisijoina ristiriitaisia, minkä seurauksena he purkavat sekä romaanin kuvaaman maskuliinisen hegemonian ylläpitämiä käytäntöjä että ekfrasiksen käsitteeseen liitettyä sukupuolittuneisuutta. Vaikka Molinan seksuaali-identiteetti pohjaa erittäin heteronormatiiviseen ja valtavirtaelokuvien representoimaan sukupuolikuvastoon, samalla Molina rikkoo vallitsevia normeja. ${ }^{17}$ Hyväksyessään yhteiskunnan asettamat säännöt miesten ja naisten rooleista ja ominaisuuksista Molina eroaa selvästi Valentínista. Jälkimmäinen puolestaan korostaa liberaalia ja tasa-arvoista sukupuolikäsitystään esimerkiksi ihailemalla entisen tyttöystävänsä haluttomuutta alistua miehen tahtoon (HS 155), ja kritisoimalla Molinan konservatiivisia näkemyksiä naisten asemasta ja velvollisuuksista (HS 271).

Heteronormatiivisen kulttuurin asenteet vaikuttavat kuitenkin myös Valentíniin. Teoksen alkupuolella hän nolostuu esittämästään kritiikistä Molinan "naiseutta” kohtaan, sillä hän tajuaa viittaavansa vastustamaansa käsitykseen naisen alempiarvoisuudesta (HS 35; ks. myös Rice-Sayre 1986, 252). Lisäksi ensimmäisenä elokuvana selostetun Cat Peoplen yhteydessä Valentín kysyy Molinalta, kumpaan naishahmoon tämä samastuu, "Irenaan vai arkkitehtityttöön" (HS 31), ottamatta huomioon sitä mahdollisuutta, että tämä voisi samastua miespuoliseen henkilöhahmoon. Molemmat omaksuvat jo romaanin alussa strereotyyppisen miehisen ja naisellisen asenteen toisiaan kohtaan, ja osoittautuvat jossakin määrin kulttuurisesti määritellyn sukupuolisuuden vangeiksi (ks. Merrim 1987, 278; Rice-Sayre 1986, 252).

Sellitoverien välille muodostuvaa suhdetta voi pitää kuitenkin irtiottona kahlitsevista sukupuoleen ja seksuaalisuuteen liittyvistä normeista. Miesten välinen kommunikaatio sekä Valentínin ailahtelu heteronormatiivisten odotusten ja homoeroottisten aktien välillä tekevät seksuaalisuuden problematiikasta näkyvän ja merkittävän osan romaanin kerrontaa. Kiinnostava yksityiskohta sukupuolten ja seksuaalisuuden ilmentämisen tematiikassa on se, miten Molina pyrkii feminisoimaan Valentínia kutsumalla tätä toisinaan Valentinaksi (HS 45). Lisäksi on muistettava, että vaikka Molina uskaltaa poiketa avoimesti yhteiskunnan sallimista sukupuoli- ja seksuaalinormeista, homoseksuaalisuus on syy hänen vankeudelleen ja rakkauselämän vaikeuksille.

Ekfrasiksen oletetun sukupuolittuneisuuden ja teoksen välistä suhdetta voi tar- 
kastella vielä lähemmin ekfrastisten jaksojen kannalta. Yhtältä feminiininen Molina osoittaa paradoksaalisesti jonkinasteista autoritääristä miehisyyttä kielellistäessään omien halujensa mukaisesti näkemiään elokuvia. Toisaalta hänen tekonsa kielii naiseuden voimasta hänen antaessaan äänen rakastamilleen ja naiskatsojiin vetoaville elokuville sekä niiden sankarittarille. Siten Molina - ja samalla romaani - puolustaa hempeiden melodraamojen olemassaolon oikeutusta ja tarjoaa niille uuden esityskanavan. Heffernania mukaillen voi väittää, että Molinan toiminnassa on kyse ekfrasiksen aiheuttamasta vallankumouksesta, jossa kuva taistelee sanaa vastaan (ks. 1993, 7). Onkin mahdollista sanoa, että Hämähäkkinaisen suudelmassa ilmenevä ekfrastinen prosessi yhtäältä painottaa konservatiivisen sukupuolijaottelun ja heteronormatiivisuuden olemassaoloa ja toisaalta ilmaisee sukupuolittavaan valtaan kohdistuvaa vastarintaa. Koko teosta ajatellen on kuitenkin perustellumpaa todeta, ettei väite ekfrasiksen sukupuolipositioista saa perustetta romaanin kerronnassa, vaan dikotomia päinvastoin hajoaa.

Näkemys ekfrasiksen sukupuolittuneisuudesta on erityisen ongelmallinen jaksoissa, joissa Valentín on ekfrastisena puhujana. Hänen esittämänsä ekfrasikset ovat korostuneen maskuliinisia ja niiden kuvasto on hyvin miehinen ("nuorimies joka on valmis vaikka antamaan henkensä puolustaessaan periaatteitaan" HS 140), joten kuvauksen kohde ei itsessään ilmennä perinteistä naisellista objektiutta. Siten se ei siis asetu vastakkain miehisen sanan kanssa vaan myötäilee sitä. (Vrt. Heffernan 1993, 1.) Valentínin roolia elokuvien sanallistajana on tutkittu jonkin verran. Esimerkiksi Roberto Echavarrenin $(1991,583)$ mukaan rationaalisuuden nimeen vannova Valentín pitää etäisyyttä valheellisena pitämäänsä kerrontamuotoon eli elokuvien kuvailemiseen, sillä hän haluaa hallita diskurssia täysin ja välttää sitä tahraavia sanoja. Romaanin lopussa, unessa ja morfiinin vaikutuksen alaisena Valentín ajautuu tahtomattaan ekfrastiseksi kertojaksi, mutta silloinkaan puheesta ei puutu poliittis-maskuliinisia sävyjä: "kunhan olen syönyt ja nukkunut vähän, voimani palaavat, sillä toverini odottavat minua takaisin jatkamaan ikuista taistelua” (HS 312).

Romaanissa esitetyt elokuvien ekfrasikset ja niiden ilmentämät sukupuolipositiot yhdistyvät myös vallan kysymyksiin. Laura Rice-Sayre $(1986,252)$ katsoo, että elokuvia analysoidessaan Molina ja Valentín tutkailevat samalla vallitsevan sukupuolijärjestelmän epäonnistuneisuutta sekä mahdollisuutta vapaampaan yhteiskuntaan. Keskustellessaan elokuvissa esiintyvistä valta-asetelmista heidän on myös mahdollista tutkia vallan mekanismeja (mt., 250). ${ }^{18}$ Lisäksi Rice-Sayre tulkitsee, että Molinan ja Valentínin välinen dialogi ilmentää oman minän rakentumista ja sitä, miten tukahduttavat yhteiskunnalliset instituutiot rajoittavat ihmissuhteita (mt., 248). Rice-Sayren näkemykset mukailevat kirjailijan omia ajatuksia sukupuolikäsitysten jähmeydestä sekä siitä, että selli esittää yhteiskunnan toimintaa pienoiskoossa (Christ 1991, 574). Kuten analyysini on osoittanut, valtasuhteet ulottuvat myös vankiselliin. Molinan vanhoista Hollywood- 
elokuvista omaksuttu naiskuva kuitenkin vihjaa, ettei hän halua päästä valta-asemaan seksuaalisessa suhteessa, vaan hän tahtoo alistua vahvan miehen tahtoon: "aviomieheni [--] pitää märätä, jotta hän tuntisi olonsa hyväksi. Se on luonnollista, sillä niin hän... on mies talossa." (HS 270.)

Vankien välisessä suhteessa ja esitetyissä elokuvatarinoissa ilmenevästä vallankäytöstä huolimatta romaanin verinen loppu vakuuttaa lukijan Molinan uhrautuvuudesta ja pyyteettömyydestä. Molinan marttyyrinomaisesta taipumuksesta vihjaa jo tekijän toiselle henkilöhahmolleen antama nimi Valentín, joka mukailee varhaisen elokuvatähden, Rudolph Valentinon nimeä (ks. Levine 2001, 258). Molinan unelmissa miehekäs Valentín on hänen näkemiensä melodraamojen kiihkeä rakastaja, joka saa heikot naiset pauloihinsa. Lisäksi täytyy muistaa Valentínin asema yhtäläisenä vallankäyttäjänä. Romaanin suutelukohtauksessa Valentín toteaa Molinan olevan "hämähäkkinainen" (HS 289), mutta Puigin elämäkerran tehneen Suzanne Jill Levinen (2001, 263) mukaan lukija ei kuitenkaan ole aivan varma, onko hämähäkkinainen sittenkin Valentín, joka saa epäpoliittisen Molinan välittämään viestinsä kapinallisille.

\section{Lopuksi: sana kuvan tukahduttajana - vai äänen antajana?}

Valtaan ja manipulaatioon liittyvät oveluuden ja petollisuuden attribuutit näkyvät ekfrasikselle luontaisessa tavassa "kaapata" kuva sanojen avulla. Grant F. Scott (1991, 302) kiinnittääkin huomiota siihen, miten ekfrasiksella on taipumus ottaa taideteos haltuun pikemmin kuin kääntää se kielelliseen muotoon. Siten visuaalisen esityksen verbalisointi ei ole ainoastaan jäljittelyn muoto vaan ovela yritys muokata ja hallita kuvaa. Scottin mukaan ekfrasiksen pyrkimykset voivat toki olla epäitsekkäitä ja jaloja, mutta halutessaan osoittaa kielen ylivaltaa ja voimaa ekfrasis on "omaa etuaan ajava" ja suorastaan "paholaismainen". (Mt.) Pohdinta paljastaa ekfrasiksen määrittelyissä usein ilmenevän personoinnin, minkä seurauksena ekfrasiksen esittäjä ja viime kädessä tekijä, saattavat helposti unohtua (ks. esim. Webb 1999, 18; Bernstein 1996, 71).

Olennaisempaa on kuitenkin pohtia, miksi tekijä antaa henkilöhahmojensa muokata kuvauksen kohteita. Romaanin kerronnan tasolla olemme nähneet, että Molina pyrkii elokuvakertomuksillaan vaikuttamaan Valentíniin. Teoksen tasolla on puolestaan perusteltua sanoa, että Puig on antanut romaanissaan puheenvuoron vähäistä arvostusta saaneelle genrelle eli melodraamoille: vaatimattomat b-elokuvat eivät ole saaneet pahemmin ääntään kuuluviin kaunokirjallisuudessa. Hämähäkkinaisen suudelmassa ekfrasikset eivät siis ainoastaan puhu elokuvista vaan ne myös puhuvat niiden puolesta (ks. Heffernan 1993, 7). Scottia mukaillen romaanin ekfrastinen prosessi on siis jossakin mär̈rin itsekästä kerronnan tasolla ja vähemmän itsekästä teoksen tasolla.

Heffernanin mukaan ekfrasis ilmentää usein ambivalenttia asennetta visuaalisia taiteita kohtaan, mikä näyttäytyy ikonofilian ja ikonofobian yhdistymisenä kerronnassa 
(mt.). ${ }^{19}$ Ekfrasikseen liittyvää ambivalenssia esiintyy myös Hämähäkkinaisen suudelmassa. Yhtäältä Molina luo voimakkaita mielikuvia kuvaamistaan elokuvista ja osoittaa niiden pelottavan voiman. Hänellä on esimerkiksi taipumus liioitella faktuaalisten elokuvien väkivaltaisia kohtauksia, kuten Cat Peoplen tapauksessa kuvatessaan pantterin hyökkäystä miehen kimppuun: "repii kaulan auki käpälällään ja hän kaatuu lattialle niin että veri vain pulppuaa” (HS 46). Toisaalta samat elokuvat selvästi ahdistavat henkilöhahmoja, sillä ne toistavat heidän asemaansa ja ongelmiaan ja saavat heidät siten tiedostamaan kipeitä ja salattuja asioita. Kontrolloiva kieli antaa kuville mahdollisuuden käynnistää erilaisia prosesseja henkilöhahmojen mielessä.

Sellissä viruvilla Molinalla ja Valentínilla on käytettävissään vain sanat, ja lukija saa kuulla heidän lausumansa ilman "kaikkitietävän” kertojan suodattavaa ääntä. Dialogimuodon voisi kuvitella tekevän romaanista erityisen läpinäkyvän, mutta tosiasiassa merkittävimmät ajatukset jäävät epäsuorien vihjausten varaan. Lukijan tärkeimpänä informaationlähteenä toimivatkin elokuvien ekfrasikset, sillä niiden kautta peilataan henkilöhahmojen asemaa ja mielentilaa. Vaikka ilmaistut sanat tulee lukea eräänlaisena koodikielenä eivätkä ne siis välitä merkitystään suoraan, sanojen voima itsessään on kiistämätön. Niiden avulla liikkuvat kuvat alkavat elä. Samalla ilmennetään kuvan vastaavaa mahtia: sanoilla voi kyllä hallita kuvia, mutta sanojen kautta herätetyt kuvat saavat oman elämänsä, Hämähäkkinaisen suudelman tapauksessa sellitoverusten ja lukijan mielikuvituksessa.

\section{Viitteet}

${ }^{1}$ Ekfrasis tulee muinaiskreikan sanoista "ek", ulos, ja "phrasis", puhe (A Greek-English Lexicon 1953, 498).

${ }^{2}$ Kuvauksista myöhäisantiikin retorisissa harjoituskirjoissa ks. Bartsch 1989, 8; Webb 1999, 11.

${ }^{3}$ Esimerkiksi sofisti Kallistratoksen 400-luvulla kirjoittamassa teoksessa Ekphraseis kuvaillaan neljäätoista fiktiivistä patsasta (Scott 1991, 301). Kuvitteellisten taideteosten kirjallinen esitys on siis verraten vanha ilmiö.

${ }^{4}$ Elokuvan ei-visuaaliset elementit ovat toki olennaisia, mutta esitysmuodon keskeisenä ominaisuutena on sen yhtenäinen kuvajatkumo. Huolimatta siitä että hyödynnän Heffernanin määritelmää, osoitan myöhemmin artikkelissani, että hänen näkemyksensä ekfrasiksesta on muilta osin ongelmallinen.

${ }^{5}$ Alaviitteiden merkityksestä teoksessa ks. esim Levine 2001, 258; Rice-Sayre 1986, 248-250; Merrim 1987, 277.

${ }^{6}$ Henkilöhahmojen mielensisäiset liikkeet on erotettu muusta tekstistä kursiivilla.

${ }^{7}$ Identiteetin käsite herättää jatkuvasti keskustelua eri tieteenaloilla. Postmoderni kulttuurinja kirjallisuudentutkimus on kyseenalaistanut identiteetin pysyvyyden ja jopa käsitteen mielekkyyden itsessään (ks. esim. Pulkkinen 2003; Hall 1999). Määrittelen seksuaaliidentiteetin subjektin omaksumaksi enemmän tai vähemmän pysyväksi konstruktioksi, joka perustuu pitkälti kulttuurin tuottamiin käsityksiin seksuaalisuuden muodoista. Identiteetin ja 
seksuaali-identiteetin problematiikasta ks. Butler 1999, 31-33.

${ }^{8}$ Heteronormativisuudella tarkoitan yhteiskunnan asettamaa ja sen ylläpitämää käsitystä heteroseksuaalisuudesta normaalina ja norminmukaisena (ks. Rossi 2003, 120).

${ }^{9}$ Molina kuvaileekin Irenaa Valentínille seuraavasti: "Hän on kuin muissa maailmoissa [--] omissa ajatuksissaan" (HS 8).

${ }^{10}$ Cat Peoplen Irenan lisäksi esimerkiksi kuvitteellisen "Meksikolaiselokuvan” naispäähenkilö joutuu miesten sorron uhriksi.

${ }^{11}$ Tällä viittaan muun muassa yhtäältä Molinan haluttomuuteen käsitellä poliittisia aiheita ja toisaalta Valentínin taipumukseen tukahduttaa emotionaalisuuttaan.

${ }^{12}$ Ekfrasiksen kohteen fiktiivisyydellä tai faktuaalisuudella ei vaikuta olevan erityistä temaattista merkitystä. Sitä vastoin lukijan näkökulmasta ekfrasiksen referentiaalisuudella voi olla merkitystä: toden ja fiktion välinen raja on erilainen riippuen siitä, tunteeko ja tunnistaako lukija Molinan selostamat faktuaaliset elokuvat vai ei.

${ }^{13}$ Elokuvien vieraus Valentínille varmistetaan hänen ja Molinan välisen ikäeron avulla (ks. Bacarisse 1988, 89).

${ }^{14}$ Molinan epistemologinen yliote ulottuu lukijaan saakka, mikäli romaanissa esitettävät faktuaaliset elokuvat eivät ole lukijalle tuttuja.

${ }^{15}$ Näin tapahtuu ainoastaan kahdesti: Cat Peoplen yhteydessä Molina muistaa, että sivuosanäyttelijän nimi on Jane Randolph (HS 50). Selostaessaan I Walked with a Zombie -elokuvaa Molina mainitsee elokuvan nimen (HS 177).

${ }^{16}$ Vaikka Molina oli vanhanaikainen ja anakronistinen henkilöhahmo romaanin julkaisuaikaan, naisasialiikkeen kuohuviin vuosina, Argentiinassa vallitsi vielä 1970-luvulla huomattavan konservatiivinen ilmapiiri (ks. Levine 2001, 262).

${ }^{17}$ Molina poikkeaa yhteiskunnan normeista omaksumalla ja toisintamalla sellaista kulttuurista ja sosiaalista sukupuolta (gender), joka on ristiriidassa hänen biologis-anatomiseen sukupuoleensa (sex) liitettyjen kulttuuristen odotusten takia ("sex/gender"- jaottelun problematiikasta ks. Liljeström 1996, 115-120; Butler 1999, 9-11).

${ }^{18}$ Miehen ja naisen väliset suhteet esitetään oppositionaalisina esimerkiksi "Meksikolaiselokuvassa" ja "Kohtalossa".

${ }^{19}$ Ernst-Peter Schneck $(1999,54)$ on samoilla linjoilla todetessaan, että ekfrasis on täynnä mielihaluja ja pelkoa.

\section{Lähteet}

HS = Hämähäkkinaisen suudelma .

baCarisse, pamela i988: The Necessary Dream: A Study of the Novels of Manuel Puig. Cardiff: University of Wales Press. Bartsch, shadi i 989: Decoding the Ancient Novel. The Reader and The Role of Description in Heliodorus and Achilles Tatius. Princeton: Princeton University Press. Bernstein, BORIS 1996: On Ekphrasis: Truth or Fiction? Teoksessa Changes in Art and Understanding it. Materials of Autumn Conferences of TUA and Estonian AICA 1994-1995. Ed. by Heie Treier. Tallinna kunstülikool toimetised 4. Tallinna: Tallinna kunstülikool. 61-77. 
BRAM, SHAHAR 2006: Ekphrasis as a shield: ekphrasis and the mimetic tradition. Word \& Image 22:4 (October-December 2006). 372-378.

BUtLer, JUdith I999/1990: Gender Trouble. Feminism and the Subversion of Identity. London: Routledge.

Cat PeOple 1942: USA. RKO Radio Pictures. Ohj. Jacques Tourneur.

Christ, Ronald i991: A Last Interview with Manuel Puig. World Literature Today, 65:4 (Autumn 1991). 571-578.

CLÜVER, CLAUS I997: Ekphrasis Reconsidered: On Verbal Representations of NonVerbal Texts. Teoksessa Interart Poetics: Essays on the interrelations of the arts and media. Ed. by Ulla Britta Lagerroth et al. 1997. Amsterdam: Rodopi. 19-33.

colás, santiago i994: Postmodernity in Latin America. The Argentine Paradigm. Durham: Duke University Press.

DYER, RICHARD 2002: Älä katso! Seksuaalisuus ja rotu viihteen kuvastossa. Toim. Martti Lahti. Suom. Martti Lahti, Taru Salakka, Juha Herkman, Silja Laine, Putte Wilhelmsson, Kaarina Nikunen, Pirjo Ahokas \& Pauliina Nurminen. Tampere: Vastapaino.

echavarren, roberto i99i: Manuel Puig: Beyond Identity. World Literature Today, 65:4 (Autumn 1991). 581-586.

the enchanted cottage i945: USA. RKO Radio Pictures. Ohj. John Cromwell. ESROCK, ELLEN I 994: The Reader's Eye. Visual Imaging as Reader Response. London: The Johns Hopkins University Press.

A Greek-english Lexicon i 953. Compiled by Henry George Liddell \& Robert Scott. Revised and augmented throughout by Henry Stuart Jones. Oxford: Oxford University Press.

GYSIN, FRITZ I989: Paintings in the house of fiction: the example of Hawthorne. Word \& Image, 5:2 (April-June 1989). 159-172.

HALL, STUART I999: Identiteetti. Toim. ja suom. Mikko Lehtonen \& Juha Herkman. Tampere: Vastapaino.

HARDwick, HANNASOFia 20II: Elokuvan ekfrasis Manuel Puigin romaanissa Hämähäkkinaisen suudelma. Painamaton pro gradu -tutkielma. Helsingin yliopisto, yleinen kirjallisuustiede.

heffernan, James A. I993: Museum of Words. The Poetics of Ekphrasis from Homer to Ashbery. Chicago: The University of Chicago Press.

I WALKed WITH a zombie I943: USA. RKO Radio Pictures. Ohj. Jacques Tourneur. Kunn, ANNeTte 2002: Everyday Magic. Cinema and Cultural Memory. London: I.B. Tauris Publishers.

KRIEGER, MURRAY I992: Ekphrasis. The Illusion of the Natural Sign. Baltimore: The Johns Hopkins University Press.

LAGERROTH, ULLA-BRITTA; LUND, HANS, HEDLING, ERIK \& GREENBLATT, STEPHEN (TOIM.) 
1997: Interart Poetics. Essays on the Interrelations of the Arts and Media. Amsterdam: Rodopi.

LeVine, SuZANne Jill 200 I: Manuel Puig and the Spider Woman. His Life and Fictions. Wisconsin: The University of Wisconsin Press.

Liljeström, MARIANne 1996: Sukupuolijärjestelmä. Teoksessa Avainsanat. 10 Askelta feministiseen tutkimukseen. Toim. Anu Koivunen \& Marianne Liljeström. Tampere: Vastapaino. 111-138.

mandelker, amy i99i: A Painted Lady: Ekphrasis in Anna Karenina. Comparative Literature 43:1 (Winter 1991). 1-19.

MCCONnell, Frank 1975: The Spoken Seen. Film \& The Romantic Imagination. Baltimore: The Johns Hopkins University Press.

merrim, stephanie 1987: Bridging the Gap: Freud and Film in Guillermo Cabrera Infante's Three Trapped Tigers and Manuel Puig's Kiss of the Spider Woman. Teoksessa Modern Latin American Fiction: A Survey. Ed. by John King. London: Faber and Faber. 268-282.

mitchell, w. J. T. I994: Picture Theory. Essays on Verbal and Visual Representation. Chicago: The University of Chicago Press.

The New princeton encyclopedia of poetry and poetics i 993. Ed. by Alex Preminger \& T. V. F. Brogan. Princeton: Princeton University Press.

THE OXFord Classic dictionary i 996. Ed. by Simon Hornblower \& Antony Spawforth. New York: Oxford University Press.

PUIG, MANUel 2009: Hämähäkkinaisen suudelma. Alkuteos: El beso de la mujer araña. Suom. Tarja Härkönen. Helsinki: Teos.

PUIG, MANUel 1989/1976: El beso de la mujer araña. Barcelona: Biblioteca de Bolsillo. pulkKinen, tuija 2003/I998: Postmoderni politiikan filosofia. 2. painos. Helsinki: Gaudeamus.

ReEves, BRIDget T. 2007: The Role of the Ekphrasis in Plot Development: The Painting of Europa and the Bull in Achilles Tatius' Leucippe and Clitophon. Mnemosyne 60, 2007. 87-101.

RiCe-Sayre, Laura i986: Domination and Desire. A Feminist-Materialist Reading of Manuel Puig's Kiss of the Spider Woman. Teoksessa Textual Analysis. Some Readers Reading. Ed. by Mary Ann Caws. New York: MLA. 245-256.

rossi, LEENA-MAIJA 2003: Heterotehdas. Televisiomainonta sukupuolituotantona. Helsinki: Gaudeamus.

SCHNECK, ERNST-PETER I999: Pictorial desires and textual anxieties: modes of ekphrastic discourse in nineteenth-century American culture. Word \& Image 15:1 (January-March 1999). 54-62.

SCOTT, GRANT F. I99I: The rhetoric of dilation: ekphrasis and ideology. Word \& Image 
7:4 (October-December 1991). 301-310.

STEIneR, Wendy 1982: The Colors of Rhetoric. Chicago: University of Chicago Press. Weвв; RUTH I999: Ekphrasis ancient and modern: the invention of a genre. Word \& Image 15:1 (January-March 1999). 7-18.

yacobi, tamar i995: Pictorial Models and Narrative Ekphrasis. Poetics Today 16:4 (Winter 1995). 599-649.

yacobi, tamar 1997: Verbal Frames and Ekphrastic Figuration. Teoksessa Interart Poetics: Essays on the interrelations of the arts and media. Ed. by Ulla Britta Lagerroth et al.1997. Amsterdam: Rodopi. 35-46.

yaCOBI, TAMAR 2000: Interart Narrative: (Un)Reliability and Ekphrasis. Poetics Today 21:4 (Winter 2000). 711-749. 